\title{
Seedling production of Coffea arabica from different cultivars in a modified hydroponic system and nursery using different containers
}

\section{Produção de mudas de diferentes cultivares de Coffea arabica em sistema hidropônico modificado e viveiro utilizando diferentes recipientes}

\section{Amador Eduardo de Lima ${ }^{1 *} \oplus$, Rubens José Guimarães ${ }^{1} \oplus$, Samuel Henrique Braga da Cunha ${ }^{1} \oplus$, Elisa de Melo Castro ${ }^{1} \odot$, Alex Mendonça de Carvalho ${ }^{2} \odot$, Mauro Magalhães Leite Faria ${ }^{1} \odot$}

\author{
${ }^{1}$ Universidade Federal de Lavras/UFLA, Departamento de Agricultura/DAG, Lavras, MG, Brasil \\ ${ }^{2}$ Universidade Estadual Paulista/UNESP, Registro, SP, Brasil \\ *Corresponding author: eduardolima@ufla.br \\ Received in June 22, 2021 and approved in October 28, 2021
}

\begin{abstract}
The development of modified hydroponic cultivation has aroused interest and its use has enabled advantages in several crops, but studies for coffee are still scarce. Thus, the objective of this research was to evaluate seedling production of three Coffea arabica cultivars (Mundo Novo IAC-376-4, Catuaí IAC-62 Amarelo and MGS Paraíso 2), in a modified hydroponic system, and to compare it with the nursery production system, using plastic polyethylene tubettes and bags. Coffee seedlings in the development phase with cotyledon leaves, were cultivated in both cultivation systems. At 90 days after the implementation of the experiment, the seedlings were analyzed for growth (height, stem diameter, total number, leaf area, root area, root and shoot dry matter weight), and physiological characteristics (chlorophyll content and stomatal conductance). For the statistical analysis, a completely randomized design (CRD) was used in a factorial scheme 3 (cultivars) $\times 2$ (containers) $\times 2$ (cultivation systems), with four replications of ten plants per plot. The innovative production system of coffee seedlings in modified hydroponics, in combination with the use of polyethylene bags, provided greater growth of coffee seedlings with better physiological characteristics. Among the cultivars tested, MGS Paraíso 2 stood out with higher seedling growth (number of leaves, stem diameter and root and shoot dry matter weight).
\end{abstract}

Index terms: Coffee; seeds; modified cultivation.

\begin{abstract}
RESUMO
O desenvolvimento do cultivo hidropônico modificado tem despertado interesse e seu uso tem possibilitado vantagens em diversas culturas agrícolas, mas estudos para o café ainda são escassos. Assim, objetivou-se com este trabalho, avaliar a produção de mudas de três cultivares de Coffea arabica (Mundo Novo IAC-376-4, Catuaí IAC-62 Amarelo e MGS Paraíso 2), em sistema hidropônico modificado e comparar com o sistema de produção em viveiro, utilizando tubetes e sacos de polietileno. Mudas de café em fase de desenvolvimento com folhas cotiledonares, foram cultivadas em ambos os sistemas de cultivo. Aos 90 dias após a implantação do experimento, as mudas foram analisadas quanto as características de crescimento (altura, diâmetro de caule, número total de folhas, área foliar, área radicular, peso da matéria seca da parte aérea e raiz) e fisiológicas (teores de clorofila e condutância estomática). Para a análise estatística foi utilizado o delineamento inteiramente casualizado (DIC) no esquema fatorial 3 (cultivares) $\times 2$ (recipientes) $\times 2$ (sistemas de cultivo), com quatro repetições de dez plantas por parcela. 0 sistema inovador de produção de mudas de café em hidroponia modificada em combinação com o uso de sacos de polietileno como recipiente, proporcionam de forma geral, melhor desenvolvimento e qualidade das mudas. Dentre as cultivares testadas, a MGS Paraíso 2 se destacou com mudas de maior crescimento (número de folhas, diâmetro de caule e peso da matéria seca de parte aérea e raízes).
\end{abstract}

Termos para indexação: Café; sementes; cultivo modificado.

\section{INTRODUCTION}

Seedling production is a fundamental step in maintaining the production chain of the coffee crop. Seedlings make it possible to transfer technologies for crop renewal and new cultivation areas.

Traditionally, Coffea arabica seedlings are produced in commercial nurseries. The main containers used are polyethylene bags containing subsurface soil substrate $(70 \%)$ and cattle manure $(30 \%)$, besides rigid polyethylene tubettes with commercial substrate consisting of nutrient-enriched ground pine bark (Vallone et al., 2010).

Seedling quality and production costs can be influenced by the substrate used, type of container and its dimensions. The availability of nutrients and water 
and, consequently, the volume and architecture of the root system, are related to the volumes of the containers (Schorn et al., 2019) and there are important parameters in seedling growth and quality (Hatamian et al., 2019; Souri; Sooraki, 2019; Saghayesh; Souri, 2018).

Thus, the search for new technologies for seedling production is important so that coffee development can make the activity more attractive and profitable for rural producers, bringing greater productive potential to crops. According to Trazzi et al. (2013), seedling quality is directly linked to yield and quality of the final product. In the context of coffee seedling production, in recent years, research has been conducted using alternative substrates (Vallone et al., 2010; Meneghelli et al., 2017), adaptation of seedlings in shading systems and full sun (Castanheira et al., 2019), among others.

Aiming at the development of new technologies for seedling production, a hydroponic system with modifications was developed by Chalfun and Faquin (2008), which has been studied with promising results in perennial species such as citrus (Gomes et al., 2019; Souza et al., 2013) and pear (Souza et al., 2015). However, for coffee, there are no established methodologies (protocols) for seedling production in this crop. Furthermore, due to the diversity of registered cultivars and their peculiarities, it is important to know the behavior of these genotypes in new cropping systems.

In this context, the objective of this research was to evaluate the production of coffee seedlings using a modified hydroponic system and nursery, in two types of containers (tubette and polyethylene bag), for three Arabica coffee cultivars.

\section{MATERIAL AND METHODS}

The experiment was carried out in the nursery of the Coffee Sector, and in the Horticulture Sector from the Department of Agriculture of Universidade Federal de Lavras (UFLA), Lavras, MG, Brazil.

Seedlings from cultivars Mundo Novo IAC-3764, Catuaí IAC-62 Amarelo and MGS Paraíso 2 were purchased in a commercial nursery, approximately 60 days after sowing, in the development phase with cotyledon leave and were transplanted (transplanting) into containers, which were conducted in two cultivation systems: 1) nurseries with sprinkler irrigation system and 2) modified hydroponic system (Chalfun; Faquin, 2008) in two types of containers (polyethylene bag - dimensions $9 \times 18 \mathrm{~cm}$ - and $120 \mathrm{~cm}^{3}$ rigid polyethylene tubette). For each treatment, four replicates with ten plants in each plot were used.
Seedlings produced in nurseries were cultivated in tubettes containing the commercial substrate Plantmax ${ }^{\circledR}$, with the addition of the slow-release fertilizer Osmocote Plus $^{\circledR}$, at the following mineral concentrations: $15 \% \mathrm{~N} ; 9 \%$ $\mathrm{K}_{2} \mathrm{O} ; 12 \% \mathrm{P}_{2} \mathrm{O}_{5} ; 0.06 \% \mathrm{Mg} ; 2.3 \% \mathrm{~S} ; 0.05 \% \mathrm{Cu} ; 0.45 \%$ $\mathrm{Fe} ; 0.06 \% \mathrm{Mn}$ and $0.02 \% \mathrm{Mo}$, at a dose of $12.5 \mathrm{~g} \mathrm{~L}^{-1}$, and in polyethylene bags using a mixture of subsurface soil $(70 \%)$, cattle manure (30\%), well tanned, enriched with 2 $\mathrm{kg}$ of dolomitic limestone; $5 \mathrm{~kg}$ of single superphosphate and $0.5 \mathrm{~kg}$ of potassium chloride for each $\mathrm{m}^{3}$ of substrate. The seedlings were placed in a nursery, on a bench suspended $80 \mathrm{~cm}$ from the ground, with a $50 \%$ shading net, where they were irrigated by a sprinkler in two watering shifts for 30 minutes a day. An average temperature of $28.7^{\circ} \mathrm{C}$ and $43.7 \%$ relative humidity were recorded during the experiment.

In a modified hydroponic system (MHS), the methodology proposed by Chalfun and Faquin (2008) was used, conducted in the 'pool' system with circulation of the nutrient solution using 960g MaxSol F21, 720g calcium nitrate and $40 \mathrm{~g}$ of EDDHA iron chelate diluted in water in a 1000-L reservoir. The seedlings were cultivated in containers (tubettes and plastic bags) filled with vermiculite and placed in the pool so as to be partially in contact with the nutrient solution, supported on flat plastic trays. The solution circulated in the pools through a motor pump set associated with the activation of the timer for 15 minutes, at each activation, four times a day. The excess of the nutrient solution in the 'pool' returned to the reservoir by gravity, through proper piping. The $\mathrm{pH}$ of the nutrient solution was maintained between 5.5 and 6.5 and the nutrient solution was changed every 30 days. The average temperature and relative humidity during the experiment were $28.4{ }^{\circ} \mathrm{C}$ and $41.5 \%$, respectively.

90 days after implementation of the experiment (seedling transplanting), the following evaluations were carried out: seedling height $(\mathrm{cm})$, mean stem diameter $(\mathrm{mm})$, total leaf number (TLN), dry matter weight of leaves (DMWL), stem (DMWS), roots (DMWR) and total (TDMW), besides total leaf area (TLA) $\left(\mathrm{cm}^{2}\right)$.

From the leaf area and dry matter weight data, the following characteristics were estimated: leaf area ratio (LAR), in $\mathrm{cm}^{2} \mathrm{~g}^{-1}$, obtained through the ratio between total leaf area (TLA) and TDMW; specific leaf area (SLA), in $\mathrm{cm}^{2} \mathrm{~g}^{-1}$, which relates the surface to the dry matter weight of the leaf itself, obtained through the ratio of TLA and DMWL; leaf weight ratio (LWR), in $\mathrm{g} \mathrm{g}^{-1}$, obtained by the ratio of DMWL and TDMW; specific leaf matter weight (SLM), in $\mathrm{mg} \mathrm{cm}^{-2}$, which is the ratio of DMWL and TLA. 
The roots were analyzed by the SAFIRA software, 'Fiber and Root Analysis System', developed by Embrapa Instrumentação, where the roots were removed from the containers, carefully washed in water, positioned next to the scale $(\mathrm{cm})$, on a black surface for contrast, and photographed with the aid of a professional camera. Subsequently, data on volume $\left(\mathrm{mm}^{3}\right)$, area $\left(\mathrm{mm}^{2}\right)$, length $(\mathrm{cm})$ and root diameter $(\mathrm{mm})$ were analyzed.

The contents of chlorophyll $\mathrm{a}, \mathrm{b}$ and total were indirectly measured, obtained through readings carried out on the leaf tissue, with the use of the portable meter clorofiLOG - CFL1030 (Falker automação agrícola), which yields values called Falker chlorophyll indices (FCI), proportional to chlorophyll absorbance (Barbieri Junior et al., 2012).

Stomatal conductance (SC) $\left(\mu \mathrm{mol} \mathrm{m} \mathrm{m}^{-2} \mathrm{~s}^{-1}\right)$ was obtained from the leaf vapor flow through the stomata to the external environment using a porometer (SC-1 Decagon Devices); readings were taken in the median region of the limbus completely extended, between 8 a.m. and 10 a.m.

The experiment was carried out in a completely randomized design (CRD), in a $3 \times 2 \times 2$ factorial scheme, with 3 cultivars (Mundo Novo IAC 376-4, Catuaí IAC62 Amarelo and MGS Paraíso 2), 2 seedling production systems (Modified hydroponics and nursery) and 2 containers (polyethylene bag and $120 \mathrm{~cm}^{3}$ tubette). Data were subjected to normality and homogeneity tests and, for analysis of variance, the statistical analysis software SISVAR $^{\circledR}$ (Ferreira, 2011) was used; for the grouping of means, the Scott-Knott test was used at 5\% significance.

\section{RESULTS AND DISCUSSION}

When analyzing the height of the seedlings produced with the different cultivars, production systems and containers, the results showed that the seedlings produced in polyethylene bags had greater growth compared to those produced in tubettes (Table 1). Lower coffee seedling height in smaller containers was also observed in other studies (Ibrahim; Kuf; Belachew, 2015, Silva et al., 2010) and may be related to less favorable conditions to the access of nutrients and moisture. Height is one of the commonly measured quality attributes of seedlings (Grossnickle; MacDonald, 2018) and may be related to higher quality seedlings (Silva et al., 2013).

Among the seedlings produced in tubettes, there is a greater growth of seedlings cultivated in a modified hydroponic system, and there was no difference between production systems for seedlings produced in polyethylene bags, except for 'Mundo Novo IAC 376-4' seedlings, which showed greater growth in MHS (Table 1). Hydroponics is an alternative method of plant nutrient supply which avoids soil-nutrient reaction complexities (Niu et al., 2015), and have the potential to generate high yield per unit area using limited land, water, and no soil (Saha; Monroe; Day, 2016).

Among the seedlings in tubettes, cultivar 'Mundo Novo IAC 376-4' (under a conventional system) had greater growth compared to the other cultivars (29.72\%) (Table 1), which can be explained by the genetic characteristic of larger size of this cultivar (Carvalho et al., 2008).

When considering only the seedlings produced in polyethylene bags, there was a difference between production systems for 'Mundo Novo IAC 376-4' (with an increase of $18.23 \%$ when grown in MHS). The greater volume of inert substrate (vermiculite) in the polyethylene bags compared to the tubettes possibly allowed greater contact with the nutrient solution, thus increasing seedling growth, especially those with genetics for larger size (Table 1).

Table 1: Height, diameter and leaf number of Coffea arabica seedlings, from cultivars Mundo Novo (MN), Catuaí and Paraíso, in modified hydroponic system (MHS) and nursery, in polyethylene bag (PB) and $120 \mathrm{~cm}^{3}$ tubette (TUB).

\begin{tabular}{|c|c|c|c|c|c|c|c|}
\hline \multirow{2}{*}{ System } & \multirow{2}{*}{ Cultivar } & \multicolumn{2}{|c|}{ Height (cm) } & \multicolumn{2}{|c|}{ Diameter (mm) } & \multicolumn{2}{|c|}{ Leaf number } \\
\hline & & PB & TUB & $\mathrm{PB}$ & TUB & PB & TUB \\
\hline \multirow{3}{*}{ MHS } & $\mathrm{MN}$ & 12.58 Aạa & $9.55 \mathrm{Ba} \underline{\mathrm{a}}$ & $2.59 \mathrm{Ab} \underline{a}$ & $1.83 \mathrm{Bb} \underline{\mathrm{b}}$ & 8.67 Aaa & $7.70 \mathrm{Bb} \underline{\mathrm{a}}$ \\
\hline & Catuaí & 11.43 Aạa & 9.13 Baa & $2.64 \mathrm{Ab} \underline{a}$ & $1.98 \mathrm{Ba} \underline{b}$ & 9.04 Aaa & 8.62 Aaa \\
\hline & Paraíso & 11.68 Aạa & 9.24 Baa & 2.80 Aaa & 2.10 Bab & 9.50 Aaa & $7.42 \mathrm{Bb} \underline{\mathrm{a}}$ \\
\hline \multirow{3}{*}{ Nursey } & $\mathrm{MN}$ & 10.64 Aab & 7.77 Bab & $2.20 \mathrm{Bb} \underline{b}$ & 2.37 Aaa & $7.40 \mathrm{Ab} \underline{\mathrm{b}}$ & $5.17 \mathrm{Bb} \underline{b}$ \\
\hline & Catuaí & 11.47 Aạa & $6.21 \mathrm{Bb} \underline{\mathrm{b}}$ & 2.54 Aaa & $2.41 \mathrm{Aa} a \underline{a}$ & 8.95 Aaa & 4.20 Bc므 \\
\hline & Paraíso & 10.90 Aaa & $5.99 \mathrm{Bbb}$ & $2.56 \mathrm{Aab}$ & 2.48 Aaa & $8.50 \mathrm{Aab}$ & 6.08 Bab \\
\hline
\end{tabular}

Means followed by the same uppercase letter in the row (difference between containers), lowercase in the column (difference between cultivars) and underlined lowercase (difference between systems), do not differ by the Scott Knott test at $5 \%$ probability. 
In the MHS, a larger stem diameter was observed in seedlings produced in a plastic bag, mainly for cultivar "MGS Paraíso 2". In the nursery, there was no difference between the containers used, except for 'Mundo Novo IAC 376-4' seedlings, which had a smaller diameter compared to the other cultivars (up to $16.36 \%$ less) when produced in polyethylene bags (Table 1).

A greater stem diameter was observed possibly due to the increase in the amount of reserves translocated from the leaves to this organ, stimulating the activity of the vascular cambium, a secondary meristem that, in dicots (such as coffee), has a function of growth in thickness (Taiz et al., 2017).

Stem diameter describes seedling sturdiness and thus helps reduce damage from drought and heat (Tsakaldimi et al., 2005; Grossnickle, 2012), and larger diameter plants will have more reserves (carbohydrates) available to be metabolized in the initial growth phase in the field (Grossnickle; MacDonald, 2018). Therefore, this characteristic is desirable, enabling greater chances of survival and less need for replanting, resulting in lower costs during the implantation or harvesting process renovation.

Total dry matter weight (TDMW) and stem diameter are relevant variables to indicate the quality of coffee seedlings (Dandengo et al., 2013). In seedlings produced in polyethylene bags, Silva et al. (2010) observed a diameter greater than that obtained in $120-\mathrm{mL}$ tubettes.

As for seedling leaf number, it was observed that the MHS provided higher values than the traditional nursery system, with the exception of seedlings of cultivar 'Catuaí IAC-62' (in polyethylene bags, under nursery conditions), which did not differ from seedlings in MHS. When the type of container used was analyzed, it was found that the seedlings produced in polyethylene bags had a greater leaf number than those produced in rigid polyethylene tubettes, with the exception of 'Catuaí IAC-62' (in MHS), which was not significantly different from those produced in polyethylene bags. Cultivar 'MGS Paraíso 2' stood out, and was among those with the highest number of leaves in most evaluations, except for seedlings in tubettes in MHS (Table 1).

It is assumed that coffee seedlings are suitable for marketing purposes when they have at least three pairs of leaves and, from that moment onwards, they are ready for planting and for a good establishment in the field. In this context, it can be observed that, in general, seedlings under MHS achieved this requirement in a shorter time since, at the end of the experiment, they presented a greater total leaf number, culminating in a faster seedling formation in this system, enabling planting anticipation, better use of the rainy season and, consequently, better vegetative and reproductive plant development in the field.
When analyzing DMWL, DMWS and TDMW of seedlings produced using different cultivars, production systems and containers (Table 2), it was found that, as observed for seedling growth (Table 1), those produced in polyethylene bags showed higher values in relation to seedlings in tubettes, in both production systems, with the exception of seedlings of 'Catuaí IAC-62' (DMWS - tubettes - MHS), 'Mundo Novo IAC 376-4' (DMWS - tubettes conventional system) and 'Mundo Novo IAC 376-4' (TDMW -tubettes - conventional system), which had values without significant differences in relation to seedlings in polyethylene bags. These results corroborate those verified by Vallone et al. (2010) who, researching the size of containers (polyethylene bags, tubettes of 50 and $120 \mathrm{~mL}$ ) under nursery conditions, found that seedlings produced in polyethylene bags yielded greater shoot dry matter weight and greater leaf area than seedlings in 120 -mL tubettes.

When analyzing the production system (nursery or MHS), it was observed that, for DMWL, DMWS and TDMW, there was no difference in growth between seedlings produced in polyethylene bags. Among the seedlings produced in tubettes, there was no difference between the two production systems for DMWS but, when DMWL is evaluated, the superiority of seedlings in tubettes produced in MHS, in relation to the traditional one, is clear. When evaluating the TDMW of seedlings produced in tubettes, it is possible to observe the superiority of those produced in MHS only over those of cultivar 'Catuaí IAC-62' (Table 2). Greater dry matter accumulation is desirable and is associated with greater growth and vigor of coffee seedlings (Dibaba, 2021).

The balance between shoot and root dry matter weight is important for seedling formation in its entirety, since they act together; the roots in the exploration process to capture water and nutrients and the leaves providing area and photosynthetic apparatus.

Regarding DMWR, the seedlings produced in polyethylene bags continued to be those with the highest growth in relation to those produced in tubettes, with the exception of cultivars 'Mundo Novo IAC 376-4' and 'Catuaí IAC-62' (in MHS) and 'Mundo Novo IAC 376-4' (in a conventional system), which had values similar to those of seedlings in polyethylene bags. Within each production system used, there were no significant differences between cultivars, except for 'Mundo Novo IAC 376-4' (polyethylene bags in conventional system), which had lower root growth compared to the others. When comparing the DMWR between the two systems, it can be observed that, for most cultivars, the seedlings produced in a conventional system had higher values than in MHS (Table 2). According to Furlan et al. (2012), under stress conditions, there is a trend 
towards greater allocation of photoassimilates in the roots at the expense of the shoot. These results, together with those verified for DMWL, may indicate that the MHS provided a more favorable environment for seedling development.

When evaluating the TLA of the seedlings, it was possible to notice the superiority of seedlings produced in polyethylene bags in the modified hydroponic system, with no significant differences for the cultivars used (Table 2). Dandengo et al. (2013) studied the influence of containers (polyethylene bags and tubettes) and different shading levels on the growth and quality of coffee seedlings, and found greater leaf area in seedlings produced in polyethylene bags. A greater leaf area implies a larger surface for light interception, which is related to higher photosynthetic rates, providing high plant growth (Pedó et al., 2018), and has great importance mainly in aspects related to production (Silva et al., 2011).

Through knowledge of the leaf area, it is possible to estimate useful indicators in the understanding of plant development, such as leaf area ratio, specific leaf area and specific leaf matter. In the evaluation of LAR, the superiority of the use of seedlings in polyethylene bags was maintained, especially in the conventional system, with no difference between the cultivars used. However, within the modified hydroponic system, the seedlings of 'Catuaí IAC-62' had higher LAR when produced in tubettes (Table 2).

Table 2: Leaf (DMWL), stem (DMWS), root (DMWR) and total (TDMW) dry matter weight, total leaf area (TLA), leaf area ratio (LAR), specific leaf area (SLA), leaf matter ratio (LMR) and specific leaf matter (SLM) of Coffea arabica seedlings, from cultivars Mundo Novo (MN), Catuaí and Paraíso in modified hydroponic system (MHS) and nursery, in polyethylene bag (PB) and $120-\mathrm{cm}^{3}$ tubette (TUB).

\begin{tabular}{|c|c|c|c|c|c|c|c|}
\hline \multirow{2}{*}{ System } & \multirow{2}{*}{ Cultivar } & \multicolumn{2}{|c|}{ DMWL (g) } & \multicolumn{2}{|c|}{ DMWS (g) } & \multicolumn{2}{|c|}{ DMWR (g) } \\
\hline & & PB & TUB & PB & TUB & PB & TUB \\
\hline \multirow{3}{*}{ MHS } & $\mathrm{MN}$ & $0.80 \mathrm{Ab} \underline{a}$ & $0.53 \mathrm{Baa}$ & $0.22 \mathrm{Aa} a \underline{a}$ & $0.16 \mathrm{Ba} a \underline{a}$ & 0.18 Aaa & $0.14 \mathrm{Aa} \underline{\mathrm{b}}$ \\
\hline & Catuaí & 1.10 Aaạ & 0.67 Baa & 0.22 Aaa & 0.16 Aaa & $0.21 \mathrm{Aa} \underline{b}$ & 0.14 Aaa \\
\hline & Paraíso & $1.20 \mathrm{Aa} a \underline{a}$ & $0.66 \mathrm{Ba} a \underline{a}$ & $0.23 \mathrm{Aa} a \underline{a}$ & $0.16 \mathrm{Ba} a \underline{a}$ & $0.24 \mathrm{Aa} \underline{b}$ & $0.13 \mathrm{Ba} \underline{b}$ \\
\hline \multirow{3}{*}{ Nursery } & $\mathrm{MN}$ & $0.57 \mathrm{Aba}$ & $0.18 \mathrm{Bab}$ & $0.16 \mathrm{Aba}$ & 0.14 Aaa & $0.18 \mathrm{Aba}$ & 0.23 Aaa \\
\hline & Catuaí & $0.88 \mathrm{Aa} \underline{a}$ & $0.14 \mathrm{Ba} \underline{b}$ & $0.23 \mathrm{Aa} \underline{a}$ & $0.10 \mathrm{Baa}$ & 0.29 Aaa & $0.18 \mathrm{Baa}$ \\
\hline & Paraíso & 1.03 Aaa & $0.27 \mathrm{Ba} \underline{\mathrm{b}}$ & $0.22 \mathrm{Aa} \underline{\mathrm{a}}$ & $0.13 \mathrm{Ba} \underline{a}$ & $0.32 \mathrm{Aa} \underline{a}$ & $0.25 \mathrm{Ba} \underline{a}$ \\
\hline \multirow{2}{*}{ System } & \multirow{2}{*}{ Cultivar } & \multicolumn{2}{|c|}{ TDMW $(\mathrm{g})$} & \multicolumn{2}{|c|}{ TLA $\left(\mathrm{cm}^{2}\right)$} & \multicolumn{2}{|c|}{$\operatorname{LAR}\left(\mathrm{cm}^{2} \mathrm{~g}^{-1}\right)$} \\
\hline & & PB & TUB & PB & TUB & $\mathrm{PB}$ & TUB \\
\hline \multirow{3}{*}{ MHS } & $\mathrm{MN}$ & $1.20 \mathrm{Aba}$ & $0.82 \mathrm{Baa}$ & 23486.29 Aaa & 15191.67 Baa & 19.75 Aaa & 18.80 Aaa \\
\hline & Catuaí & $1.53 \mathrm{Aa} a \underline{a}$ & $0.97 \mathrm{Ba} \underline{a}$ & 26554.59 Aaa & 19921.21 Baa & $17.49 \mathrm{Ba} \underline{a}$ & 21.07 Aaa \\
\hline & Paraíso & 1.68 Aaa & $0.97 \mathrm{Baa}$ & 29887.70 Aaạ & 16317.51 Baạ & 17.85 Aạa & 18.04 Aaa \\
\hline \multirow{3}{*}{ Nursery } & $\mathrm{MN}$ & $0.91 \mathrm{Ab} \underline{a}$ & 0.56 Aaa & 13291.79 Aab & 3856.86 Bab & 14.69 Aab & $7.00 \mathrm{Bab}$ \\
\hline & Catuaí & 1.40 Aaa & $0.42 \mathrm{Ba} \underline{\mathrm{b}}$ & 17834.35 Aab & $3298.52 \mathrm{Ba} \underline{b}$ & $12.90 \mathrm{Aab}$ & $7.90 \mathrm{Ba} \underline{b}$ \\
\hline & Paraíso & 1.59 Aaa & 0.66 Baa & 19097.12 Aab & 4723.34 Bab & $12.34 \mathrm{Aa} \underline{\mathrm{b}}$ & $7.17 \mathrm{Ba} \underline{\mathrm{b}}$ \\
\hline \multirow{2}{*}{ System } & \multirow{2}{*}{ Cultivar } & \multicolumn{2}{|c|}{$\mathrm{SLA}\left(\mathrm{cm}^{2} \mathrm{~g}^{-1}\right)$} & \multicolumn{2}{|c|}{$\operatorname{LMR}\left(\mathrm{g} \mathrm{g}^{-1}\right)$} & \multicolumn{2}{|c|}{$\mathrm{SLM}\left(\mathrm{mg} \mathrm{cm}^{-2}\right)$} \\
\hline & & PB & TUB & PB & TUB & PB & TUB \\
\hline \multirow{3}{*}{ MHS } & $\mathrm{MN}$ & 29.62 Aaa & 29.29 Aaạ & $0.7855 \mathrm{Aba}$ & 0.7735 Aaa & 0.0343 Aaạ & $0.0348 \mathrm{Aa} \underline{\mathrm{b}}$ \\
\hline & Catuaí & 24.32 Aaa & 30.54 Aaa & 0.8295 Aaạ & 0.7997 Aaa & 0.0425 Aaạ & 0.0333 Aaa \\
\hline & Paraíso & 24.99 Aaạ & 26.07 Aaạ & 0.8385 Aaạ & 0.8050 Aaạ & $0.0400 \mathrm{Aa} \underline{\mathrm{b}}$ & $0.0390 \mathrm{Aab}$ \\
\hline \multirow{3}{*}{ Nursery } & $\mathrm{MN}$ & 23.36 Aaa & 21.14 Aab & 0.7780 Aaạ & $0.5682 \mathrm{Bb} \underline{\mathrm{b}}$ & 0.0433 Aaạ & $0.0485 \mathrm{Ab} \underline{\mathrm{a}}$ \\
\hline & Catuaí & 20.24 Aaa & 24.10 Aab & 0.7972 Aaạ & $0.5835 \mathrm{Bb} \underline{\mathrm{b}}$ & 0.0503 Aaa & $0.0445 \mathrm{Aba}$ \\
\hline & Paraíso & 19.24 Aaa & 17.23 Aab & 0.8215 Aaa & $0.6730 \mathrm{Ba} \underline{\mathrm{b}}$ & 0.0545 Aaa & $0.0588 \mathrm{Aa} \underline{\mathrm{a}}$ \\
\hline
\end{tabular}

Means followed by the same uppercase letter in the row, lowercase in the column and underlined lowercase in the system, do not differ by the Scott Knott test at $5 \%$ probability. 
When SLA was evaluated, it was found that, among all treatments, there was a significant difference only with the superiority of values for seedlings produced in MHS in relation to the conventional system, when produced in tubettes, with no differences between containers or cultivars used (Table 2). SLA represents the ratio between leaf area and leaf dry biomass; it is a factor of physiological importance, as it describes the destination of leaf biomass per unit area (Cunha et al., 2019).

For leaf matter ratio (LMR), it is observed that, among the seedlings produced under MHS, there was no difference between the containers used and, in the case of polyethylene bags, the seedlings produced with 'Mundo Novo IAC 376-4' presented lower values than the others. However, the seedlings produced in plastic tubettes had higher LMR values in the modified hydroponic system compared to the conventional system and, among the seedlings produced in polyethylene bags, there was no difference between production systems. With the use of the conventional system for seedling production, those in polyethylene bags were superior in relation to those in tubettes (Table 2).

Young plants tend to have higher LMR values since, at the beginning of growth, a greater allocation of photoassimilates to the leaves is necessary in relation to other tissues, which will grow from the material transported from the leaves (Cunha et al., 2019). In this context, it can be inferred that the seedlings produced in the nursery with tubettes had their development delayed for presenting lower values in relation to the other treatments, that is, the conventional system proved to be less efficient than MHS, which can also be verified by observing data related to height and number of leaves (Table 1). Among the seedlings in tubettes and conventional system (nursery), 'MGS Paraíso 2' presented a higher LMR value than the others (Table 2).

Specific leaf matter (SLM) represents the ratio between DMWL and leaf area, and is related to leaf thickness (Cunha et al., 2019). As for the evaluation of this variable, no significant differences were observed between the values obtained for the seedlings of polyethylene bags or plastic tubettes and, among the seedlings produced in a modified hydroponic system, there was no effect of cultivars. Comparing the effect of seedlings produced between the modified hydroponic system and those produced in a nursery (conventional system), it can be observed that SLM values were lower when using seedlings of 'MGS Paraíso 2' (tubettes or polyethylene bags) and 'Mundo Novo IAC 376-4' (in tubettes). Among the seedlings produced in nurseries and in tubettes, 'MGS Paraíso 2'obtained higher values than the others in terms of SLM (Table 2).
When the seedling production systems (nursery or MHS) were evaluated regarding root volume, it was found that, with the use of seedlings in polyethylene bags, there was no significant difference in most treatments, except for seedlings of 'Catuaí IAC-62' produced in nurseries, which presented lower values. Still evaluating the difference in the use of production systems, this time with seedlings produced in tubettes, it was observed that the conventional system (nursery) provided higher values than the modified hydroponic system (except for 'Mundo Novo IAC 376-4', with values similar to the conventional one) (Table 3 ).

For the seedlings of the modified hydroponic system, there was a difference in root volume between cultivars, with higher values for 'MGS Paraíso 2' produced in polyethylene bags $(5,134.01)$ and for 'Mundo Novo IAC $376-4^{\prime}$, in the case of production in tubettes $(3,137.68)$. When the seedlings were evaluated in a conventional system (nursery), it was found that, for 'Catuaí IAC-62' (in tubettes), the values were similar to those of the seedlings in polyethylene bags and, for 'Mundo Novo IAC 376-4', there was a decrease in root volume when produced in polyethylene bags (Table 3), evidencing the individual response of each cultivar to the studied systems.

In seedlings of the conventional system (nursery), there was also a difference in root volume between cultivars, with higher values for 'MGS Paraíso 2' produced in polyethylene bags $(4,943.03)$ in relation to the others, with values of up to $96.16 \%$. A similar behavior was observed in the evaluation of the root surface area and 'MGS Paraíso 2' stood out among the others (18,624.19 for MHS and 17,996.51 for nursery) (Table 3).

Even when evaluating root surface area, it could be verified that there was no difference in the values obtained between the two production systems, when comparing seedlings produced in polyethylene bags. However, when evaluating the seedlings produced in plastic tubettes, it was observed that seedlings produced in a conventional system had higher values (Table 3 ). Although the tubettes seedlings in nursery have a larger root surface area, this fact did not provide the best vegetative development.

When the seedling production systems (nursery or MHS) were evaluated regarding root diameter, it was found that, with the use of seedlings in polyethylene bags, there was no significant difference between treatments. Still evaluating the difference in the use of production systems, this time with seedlings produced in tubettes, it was found that the conventional system (nursery) provided lower values than the modified hydroponic system (except for 'Catuaí IAC-62', which presented values similar to MHS (Table 3). 
Table 3: Volume, surface area, diameter and root length of Coffea arabica seedlings, from cultivars Mundo Novo (MN), Catuaí and Paraíso in modified hydroponic system (MHS) and nursery, in polyethylene bag (PB) and 120$\mathrm{cm}^{3}$ tubette (TUB).

\begin{tabular}{|c|c|c|c|c|c|}
\hline \multirow{2}{*}{ System } & \multirow{2}{*}{ Cultivar } & \multicolumn{2}{|c|}{ Volume $\left(\mathrm{mm}^{3}\right)$} & \multicolumn{2}{|c|}{ Surface area $\left(\mathrm{mm}^{2}\right)$} \\
\hline & & PB & TUB & PB & TUB \\
\hline \multirow{3}{*}{ MHS } & $\mathrm{MN}$ & 2705.30 Aca & 3137.68 Aaa & 9563.22 Aca & 10371.76 Aab \\
\hline & Catuaí & 4303.64 Aba & 2391.71 Bb $\underline{b}$ & 15300.14 Aba & $8870.56 \mathrm{Ba} \underline{\mathrm{b}}$ \\
\hline & Paraíso & 5134.01 Aaạ & $2434.51 \mathrm{Bb} \underline{b}$ & 18624.19 Aaạ & $8228.10 \mathrm{Ba} \underline{b}$ \\
\hline \multirow{3}{*}{ Nursery } & $\mathrm{MN}$ & 2519.84 Bca & $3565.38 \mathrm{Aa} a \underline{a}$ & $8811.90 \mathrm{Bc} \underline{\mathrm{a}}$ & 13170.08 Aaạ \\
\hline & Catuaí & $3348.69 \mathrm{Ab} \underline{b}$ & 3581.06 Aaạ & 13338.11 Aba & 11871.49 Aaa \\
\hline & Paraíso & 4943.03 Aaạ & 3593.17 Baa & 17996.51 Aaạ & 13621.35 Baạ \\
\hline \multirow{2}{*}{ System } & \multirow{2}{*}{ Cultivar } & \multicolumn{2}{|c|}{ Diameter (mm) } & \multicolumn{2}{|c|}{ Length (cm) } \\
\hline & & PB & TUB & PB & TUB \\
\hline \multirow{3}{*}{ MHS } & $\mathrm{MN}$ & $0.7177 \mathrm{Ba} \underline{a}$ & 0.8335 Aaa & 14.7667 Bb $\underline{b}$ & 24.2082 Aba \\
\hline & Catuaí & 0.6500 Aaạ & 0.7195 Aaạ & 16.8125 Bab & 27.5332 Aaạ \\
\hline & Paraíso & 0.7357 Aaạ & $0.7712 \mathrm{Aa} a \underline{a}$ & 17.9870 Baạ & 21.5915 Aca \\
\hline \multirow{3}{*}{ Nursery } & $\mathrm{MN}$ & 0.7255 Baạ & $0.6207 \mathrm{Aa} \underline{b}$ & 18.9417 Aaạ & 14.1835 Bab \\
\hline & Catuaí & 0.6090 Aaạ & 0.6425 Aaa & 20.3542 Aaạ & 14.6247 Bab \\
\hline & Paraíso & 0.6495 Aaạ & $0.6170 \mathrm{Aab}$ & 19.7540 Aaạ & 14.8250 Bab \\
\hline
\end{tabular}

Means followed by the same uppercase letter in the row, lowercase in the column and underlined lowercase in the system, do not differ by the Scott Knott test at $5 \%$ probability.

It was observed that the seedlings produced in MHS, in tubettes, had a smaller surface area compared to those grown in a nursery. Silveira et al. (2014) studied coffee seedlings (Mundo Novo and Catuaí) in flooded and irrigated systems, and observed that the stress caused by flooding caused a reduction in the area of absorbent roots. Although MHS did not maintain a flooding condition in this research, as it is a hydroponic system, the seedlings remained partially in contact with the nutrient solution that was absorbed by capillary action and, despite a smaller root surface area, they showed greater length and mean diameter for most genotypes.

When assessing the effect of the production system used, it was observed that MHS provides seedlings with greater root length when the seedlings are produced in tubettes. Seedlings produced in polyethylene bags, on the other hand, have greater root length when in the conventional system (except for cultivar 'MGS Paraíso 2', which stands out in the two proposed systems (Table 3).

It can be observed that seedlings produced in a modified hydroponic system, in tubettes, have higher root length values than those produced in the same system, but in polyethylene bags. This fact can be explained by the limitation to root growth in polyethylene bags that possibly interfered with their length. However, the opposite is observed in nursery-produced seedlings, which can be explained by the 'natural pruning' of the roots that come out through the lower part of the tubette, and without the protection of the substrate, their growth is limited.

There was no difference in root length between the cultivars used for seedling production in the nursery, regardless of the container used. However, when seedlings were produced in a modified hydroponic system, the cultivars had different responses, with 'MGS Paraíso 2' $(17,9870)$ and 'Catuaí IAC-62' (16.8125) more adapted to production in polyethylene bags and 'Catuaí IAC- 62' $(27,5332)$ also in rigid polyethylene tubettes (Table 3 ).

The greater root development for the volume and surface area of seedlings produced in tubettes in the nursery in relation to MHS may be related to the need to search for nutrients in the substrate for most cultivars. On the other hand, in MHS, with the use of vermiculite, which is an inert and light substrate, in 'pools' with nutrient solution, it is observed that seedlings tend to invest their metabolic resources in developing root length and diameter. 
According to Grossnickle and Mc. Donald (2018), the greater root system size enhances water uptake and transport to foliage, respectively, confering a higher chance of avoiding plant stress and enhancing seedling growth.

During the photosynthetic process, chlorophylls are responsible for capturing solar radiation. Assessing the levels of chlorophyll a and total, it is possible to observe higher values obtained in the modified hydroponic system, compared to the conventional one, regardless of the container or cultivar used. It is also possible to observe the superiority of seedlings produced in polyethylene bags, in relation to those produced in tubettes in the case of the conventional system. There were no significant differences between containers in the modified hydroponic system when evaluating chlorophyll a and total. Cultivars did not interfere in the results of chlorophyll a and total in any of the treatments (Table 4).

When evaluating the content of chlorophyll $b$, it can be observed that the use of the modified hydroponic system yielded higher values in the seedlings, regardless of the container or cultivar used and this could be due to better root growth and availability of mineral nutrients, enhancing chlorophyll biosynthesis (Mohammadipour;
Souri, 2019). There was no interference of cultivars when evaluating chlorophyll $\mathrm{b}$ contents in seedlings produced in tubettes, in the two systems tested (nursery and MHS) but, when the same characteristic was evaluated in seedlings produced in polyethylene bags, the three cultivars showed higher values of chlorophyll b in MHS (Table 4). Due to the ability to modify the size and location of the antenna complex, involved in the absorption of light energy, higher levels of this chlorophyll can optimize the photosynthetic process and, therefore, increase biomass production (Voitsekhovskaja; Tyutereva, 2015).

Cavatte et al. (2012) studied the effect of water deficit on the growth and physiology of C. arabica and found that, as the water deficit intensified, the chlorophyll contents were reduced due to the formation and, consequently, the action of reactive oxygen species (ROS) which, according to Carlin, Rhein and Santos, (2012), cause gradual damage to chlorophyll molecules. In this study, when observing the results obtained for seedlings in nursery, regarding the use of plastic tubettes in relation to the polyethylene bag, it is clear that the lower storage capacity and water retention in the containers may have yielded lower chlorophyll rates.

Table 4: Chlorophyll a, b and total and stomatal conductance (SC) of Coffea arabica seedlings, from cultivars Mundo Novo (MN), Catuaí and Paraíso in modified hydroponic system (MHS) and nursery, in polyethylene bag (PB) and $120-\mathrm{cm}^{3}$ tubette (TUB).

\begin{tabular}{|c|c|c|c|c|c|}
\hline \multirow{2}{*}{ System } & \multirow{2}{*}{ Cultivar } & \multicolumn{2}{|c|}{ Chlorophyll a (ICF) } & \multicolumn{2}{|c|}{ Chlorophyll b (ICF) } \\
\hline & & PB & TUB & PB & TUB \\
\hline \multirow{3}{*}{ MHS } & $\mathrm{MN}$ & 388.08 Aaa & 360.75 Aaa & 182.25 Aaa & $142.50 \mathrm{Baa}$ \\
\hline & Catuaí & 400.25 Aaạ & 375.50 Aaạ & 198.08 Aaạ & $162.83 \mathrm{Baa}$ \\
\hline & Paraíso & 398.17 Aaa & 366.00 Aaạ & 194.75 Aaa & $150.50 \mathrm{Baa}$ \\
\hline \multirow{3}{*}{ Nursery } & $\mathrm{MN}$ & $328.08 \mathrm{Aa} \underline{\mathrm{b}}$ & $81.58 \mathrm{Ba} \underline{b}$ & 117.33 Ab $\underline{b}$ & 21.92 Bab \\
\hline & Catuaí & $319.50 \mathrm{Aab}$ & $74.50 \mathrm{Bab}$ & 108.33 Ab $\underline{b}$ & $19.58 \mathrm{Bab}$ \\
\hline & Paraíso & 354.92 Aaạ & $84.50 \mathrm{Ba} \underline{b}$ & 144.17 Aab & $23.50 \mathrm{Bab}$ \\
\hline \multirow{2}{*}{ System } & \multirow{2}{*}{ Cultivar } & \multicolumn{2}{|c|}{ Total chlorophyll (ICF) } & \multicolumn{2}{|c|}{$\mathrm{SC}\left(\mu \mathrm{mol} \mathrm{m} \mathrm{m}^{-2} \mathrm{~s}^{-1}\right)$} \\
\hline & & PB & TUB & PB & TUB \\
\hline \multirow{3}{*}{ MHS } & $\mathrm{MN}$ & 570.33 Aaa & 503.25 Aaa & 184.87 Aaa & 191.26 Aaa \\
\hline & Catuaí & 598.33 Aaa & 538.33 Aaạ & 181.875 Aaa & 159.80 Aaa \\
\hline & Paraíso & 592.92 Aaa & 516.50 Aaa & 147.96 Abb & 131.30 Abl \\
\hline \multirow{3}{*}{ Nursery } & $\mathrm{MN}$ & $445.42 \mathrm{Aa} \underline{b}$ & $103.50 \mathrm{Ba} \underline{b}$ & 192.11 Aaa & 193.95 Aaa \\
\hline & Catuaí & 427.83 Aab & $94.08 \mathrm{Ba} \underline{b}$ & 200.74 Aaa & 191.83 Aaa \\
\hline & Paraíso & 499.08 Aab & 108.00 Bab & 203.23 Aaa & 163.98 Bba \\
\hline
\end{tabular}

Means followed by the same uppercase letter in the row, lowercase in the column and underlined lowercase in the system, do not differ by the Scott Knott test at $5 \%$ probability. 
Regarding the influence of the production system (nursery or MHS) on seedling stomatal conductance, it was observed that there was no difference, except for the seedlings of 'MGS Paraíso 2' which, regardless of the container used, had lower values for MHS. As for the containers used, it can be observed that there was no difference, except for 'MGS Paraíso 2', in nursery, reaching lower values (163.98) when produced in tubettes. Assessing the effect of cultivars on stomatal conductance, it was found that 'MGS Paraíso 2' presented lower values under almost all conditions tested, remaining similar to the others only in the case of seedlings produced in polyethylene bags in a nursery environment (conventional) (Table 4).

The adaptation of plants to a given environment can be better understood by knowing the physiological mechanisms involved in the regulation of their metabolism, such as photosynthetic rate, stomatal conductance, transpiration and water use efficiency, which can indicate the level of adaptation to a condition of stress or even differences between genotypes under an optimal cultivation condition (Verissimo et al., 2010). Stomatal conductance can be affected by water stress and temperature (Iseki; Olaleye, 2020; Castanheira et al., 2019). Although the seedlings of 'MGS Paraíso 2' had lower stomatal conductance values, this cultivar had good performance for several growth characteristics (Table 1), dry matter weight (Table 2), root system (Table 3 ) and chlorophylls (Table 4), showing that the lowest SC value does not necessarily imply less development.

Given the above, it was possible to verify that MHS is a viable and promising technique for the production of coffee seedlings, providing gains in seedling quality, reduction in the formation period, better phytosanitary control, in addition to better water use. Mukeshambala et al. (2014) studied the amount of water necessary for the formation of coffee seedlings in different containers and found that, for the production of 1000 seedlings, a daily consumption of approximately $13 \mathrm{~L}$ for production in polyethylene bags were necessary, besides $64 \mathrm{~L}$ for production in tubettes. In this study, an average consumption of $13 \mathrm{~L}$ per day was verified for MHS for the production of seedlings in polyethylene bags and $7 \mathrm{~L}$ when using tubettes.

\section{CONCLUSIONS}

The innovative system for the production of coffee seedlings in modified hydroponics, combined with the use of polyethylene bags as a container, generally provides better seedling development and quality, when compared to the nursery. Cultivar 'MGS Paraíso 2' stands out with higher seedling growth (leaf number, stem diameter and root and shoot dry matter weight).

\section{AUTHOR CONTRIBUTION}

Conceptual Idea: Lima, A.E.; Guimarães, R.J.; Methodology design: Lima, A.E.; Guimarães, R.J.; Data collection: Lima, A.E.; Castro, E.M.; Cunha, S.H.B.; Data analysis and interpretation: Lima, A.E.; Guimarães, R.J.; Castro, E.M.; Cunha, S.H.B.; and Writing and editing: : Lima, A.E.; Guimarães, R.J.; Castro, E.M.; Cunha, S.H.B.; Carvalho, A.M.; Faria, M.M.L.

\section{ACKNOWLEDGMENTS}

The authors would like to thank FAPEMIG, CAPES and CNPq, for the financial support.

\section{REFERENCES}

BARBIERI JUNIOR, E. et al. Um novo clorofilômetro para estimar os teores de clorofila em folhas do capim Tifton 85. Ciência Rural, 42(12):2242-2245, 2012.

CARLIN, S. D.; RHEIN, A. F. L.; SANTOS, M. M. D. Efeito simultâneo da deficiência hídrica e do alumínio tóxico no solo na cultivar IAC91-5155 de cana-de-açúcar. Semina: Ciências Agrárias, 33(2):553-563, 2012.

CARVALHO, C. H. S. Cultivares de café: Origem, característica e recomendações. Brasília: EMBRAPA Café, 2008. 334p.

CASTANHEIRA, D. T. et al. Agronomic techniques for mitigating the effects of water restriction on coffee crops. Coffee Science, 14(1):104-115, 2019.

CAVATTE, P. C. et al. Could shading reduce the negative impacts of drought on coffee? A morphophysiological analysis. Physiologia Plantarum, 144(2):111-122, 2012.

CHALFUN, N. N. J.; FAQUIN, V. Hidromudas: Processo de produção de porta enxertos e mudas frutíferas, florestais e ornamentais enxertadas em hidroponia. (BRN.PI 08027927), Rio de Janeiro: INPI, 2008.

CUNHA, S. H. B. et al. Influência da qualidade de luz no crescimento e acúmulo de voláteis de Mentha spicata cultivada in vitro. Scientia Plena, 15(9):1-11, 2019.

DANDENGO, M. C. J. D. et al. Crescimento e qualidade de mudas de café conilon produzidas em diferentes recipientes e níveis de sombreamento. Coffee Science, 8(4):500-509, 2013.

DIBABA, B. Dry matter yield and nutrient uptakes of arabica coffee seedlings as influenced by lime and coffee husk compost amendments at Western Ethiopia. Pelita Perkebunan, 37(2):97-106, 2021.

FERREIRA, D. F. Sisvar: A computer statistical analysis system. Ciência e Agrotecnologia, 35(6):1039-1042, 2011. 
FURLAN, A. et al. Physiological and biochemical responses to drought stress and subsequent rehydration in the symbiotic association peanut Bradyrhizobium sp. International Scholarly Research Network, Article ID 318083:1-8, 2012.

GOMES, W. A. et al. Leading systems and viability of citric buds in hydroponics. Revista Caatinga, 32(2):364-369, 2019.

GROSSNICKLE, S. C.; MACDONALD, J. E. Why seedlings grow: Influence of plant attributes. New Forests, 49:1-34, 2018.

GROSSNICKLE, S. C. Why seedlings survive: Influence of plant attributes. New Forests, 43:71-738, 2012.

HATAMIAN, M. et al. Interaction of lead and cadmium on growth and leaf morphophysiological characteristics of European hackberry (Celtis australis) seedlings. Chemical and Biological Technologies in Agriculture, 7:9, 2020.

IBRAHIM, M.; KUFA, T.; BELACHEW, K. Effect of pot sizes and coffee cultivars on emergence and subsequent seedling growth of coffee (Coffea Arabica L.), South Western Ethiopia. Journal of Natural Sciences Research, 5(7):1-10, 2015.

ISEKI, K.; OLALEYE, O. A new indicator of leaf stomatal conductance based on thermal imaging for field grown cowpea. Plant Production Science, 23(1):136-147, 2020.

MENEGHELLI, L. A. M. et al. Produção de mudas de café arábica em substrato composto por resíduo da secagem dos grãos. Coffee Science, 12(3):381-388, 2017.

MOHAMMADIPOUR, N.; SOURI, M. K. Effects of different levels of glycine in the nutrient solution on the growth, nutrient composition and antioxidant activity of coriander (Coriandrum sativum L.). Acta Agrobotanica, 72(1):1759, 2019.

MUKESHAMBALA, F. F. et al. Irrigation frequency and doses of polymer hydro retainer in seedlings of coffee formation. Coffee Science, 9(1):61-67, 2014.

NIU, F. et al. Morphological response of eucalypts seedlings to phosphorus supply through hydroponic system. Scientia Horticulturae, 194(14):295-303, 2015.

PEDÓ, T. et al. Plant growth and vigor of bean seeds in response to the exogenous application of gibberellic acid. Revista de Ciências Agrárias, 41(3):181-190, 2018.

SCHORN, L. A. et al. Definição de idades ótimas para expedição de mudas de Araucaria angustifolia (Bertol.) Kuntze (Araucariaceae) em função de sua qualidade e volume de recipientes. Biotemas, 32(4):19-27, 2019.

SAGHAIESH, P. S.; SOURI, M. K. Root growth characteristics of khatouni melon seedlings as affected by potassium nutrition. Acta Scientiarum Polonorum Hortorum Cultus, 17(5):191-198, 2018.

SAHA, S.; MONROE, A.; DAY, M. R. Growth, yield, plant quality and nutrition of basil (Ocimum basilicum L.) under soilless agricultural systems. Annals of Agricultural Sciences, 61(2):181-186, 2016.

SILVA, A. P. et al. Coffee seedlings in different substrates and protected environments. Engenharia Agrícola, 34(4):589600, 2013.

SILVA, J. I. et al. Desenvolvimento de mudas de Coffea canephora Pierre ex A. froehner em diferentes combinações de substrato e recipiente. Coffee Science, 5(1):38-48, 2010.

SILVA, W. Z. et al. Métodos de estimativa de área foliar em cafeeiro. Enciclopédia Biosfera, 7(13):746-759, 2011.

SILVEIRA, H. R. O. et al. Growth effects of water excess on coffee seedlings (Coffea arabica L.). Acta Scientiarum.Agronomy, 36(2):211-218, 2014.

SOURI, M. K.; SOORAKI, Y. F. Benefits of organic fertilizers spray on growth quality of chili pepper seedlings under cool temperature. Journal of Plant Nutrition, 42(6):650-656, 2019.

SOUZA, A. G. et al. Massa seca e acúmulo de nutrientes em mudas enxertadas de pereira em sistema hidropônico. Revista Brasileira Fruticultura, 37(1):240-246, 2015.

SOUZA, A. G. et al. Produção de mudas de tangerineira 'Ponkan' em sistema hidropônico. Revista Ciência Agronômica, 44(4):902-909, 2013.

TAIZ, L. et al. Fisiologia e Desenvolvimento Vegetal. (Rev.). 6. ed. Porto Alegre: Artmed, 2017. 690p.

TSAKALDIMI, M. et al. Root morphology, stem growth and field performance of seedlings of two Mediterranean evergreen oak species raised in different container types. Plant Soil, 278:85-93, 2005.

TRAZZI, P. A. et al. Substratos de origem orgânica para produção de mudas de teca (Tecton agrandis Linn. F.). Ciência Florestal, 23(3):401-409, 2013.

VALLONE, H. S. et al. Diferentes recipientes e substratos na produção de mudas de cafeeiros. Ciência e Agrotecnologia, 34(1):55-60, 2010.

VERISSIMO, V. et al. Trocas gasosas e crescimento vegetativo de quatro variedades de mandioca. Revista Raízes e Amidos Tropicais, 6:232-240, 2010.

VOITSEKHOVSKAJA, O. V.; TYUTEREVA, E. V. Chlorophyll b in angiosperms: Functions in photosynthesis, signaling and ontogenetic regulation. Journal of Plant Physiology, 189:51-64, 2015. 